\title{
TOURISM AS A VEHICLE FOR LOCAL ECONOMIC DEVELOPMENT IN SMALL TOWNS? WHEN THINGS GO WRONG: THE CASE OF ALIWAL NORTH, SOUTH AFRICA
}

\author{
Nolitha KONTSIWE \\ Centre for Development Support, University of the Free State, P.O. Box 339 \\ 9300, Bloemfontein, South Africa, e-mail: galpeppa@yahoo.com \\ Gustav VISSER* \\ Department of Geography and Environmental Studies, Stellenbosch University, \\ Private Bag X1, Matieland 7602, South Africa, e-mail: gevisser@sun.ac.za
}

\begin{abstract}
Citation: Kontsiwe N. \& Visser G., (2019). TOURISM AS A VEHICLE FOR LOCAL ECONOMIC DEVELOPMENT IN SMALL TOWNS? WHEN THINGS GO WRONG: THE CASE OF ALIWAL NORTH, SOUTH AFRICA. GeoJournal of Tourism and Geosites, 27(4), 1334-1346. https://doi.org/10.30892/gtg.27418-437
\end{abstract}

\begin{abstract}
Post-apartheid local economic development (LED) issues have been of central concern in South African economic planning. The aim of this investigation was to examine the challenges of tourism-led LED in Aliwal North, a small town in South Africa. It shows that despite the many tourism products that could potentially be deployed as a development driver for LED in this town and its hinterland, a range of challenges have frustrated such ambitions. Challenges involve poor management of key tourism products, a lack of targeted and coordinated marketing activities of the destination and a lack of a coordinated stakeholder relationship in the broader destination region, as well as limited management capacity and funding.
\end{abstract}

Key words: South Africa, Eastern Cape, Aliwal North, local economic development, tourism

\section{INTRODUCTION}

In a recent book focused on small town tourism development in South Africa, Donaldson (2018:7) makes the following observation: "Tourism-based development is a theme equally important in the developing world as in the developed world...while...metropolitan areas being positioned to become (or remain) globally competitive, there are many towns which depending on their location relative to the metropolitan region are struggling for survival with crippled service delivery and a lack of competent urban management, whereas others have been transformed into prosperous local post-productivist (agriculture-oriented) economies functioning as vibrant tourist

\footnotetext{
* Corresponding author
} 
destinations". The deployment of tourism as a development driver has taken place for good reason. Tourism has become one of the fastest growing and largest economic sectors globally (Sharpley \& Harrison, 2019). It has furthermore been associated with the creation of jobs and economic revitalisation of localities facing stagnation (Binns \& Nel, 2002; Meyer \& Meyer, 2015; Rogerson, 2019a). A significant number of destinations worldwide, including South Africa, have realised tourism's potential as a driver of socioeconomic progress (Brida \& Pulina, 2010), which has been recognised in a range of policy documents (Republic of South Africa, 2010, 2017). Small towns in South Africa have aimed to mimic these strategies and have faced similar challenges as highlighted by Donaldson (2018). Nevertheless, many small town (potential) destinations have invested in tourism with the hope of securing investment from other sources (Milne \& Ateljevic, 2001; Rogerson, 2019b; Rogerson \& Rogerson, 2019). The question arises as to why tourism is then not prioritised or not contributing to economic development in some small towns with tourism potential. The aim of this investigation was to examine these challenges facing the tourism and local economic development nexus in Aliwal North - a remote town in South Africa's Eastern Cape Province (Figure 1).

We explore how tourism could be (but is not, owing a number of factors we highlight) utilised to drive LED in a small town with tourism potential. Following a brief introduction to the study area and the methodology employed in the investigation, a number of sections of review and analysis follow. A broad context in current literature is presented. Thereafter, the policy context for the South African deployment of tourism as a local economic development driver is considered, after which the bulk of the paper focuses on the research findings. In the final section conclusions are drawn.

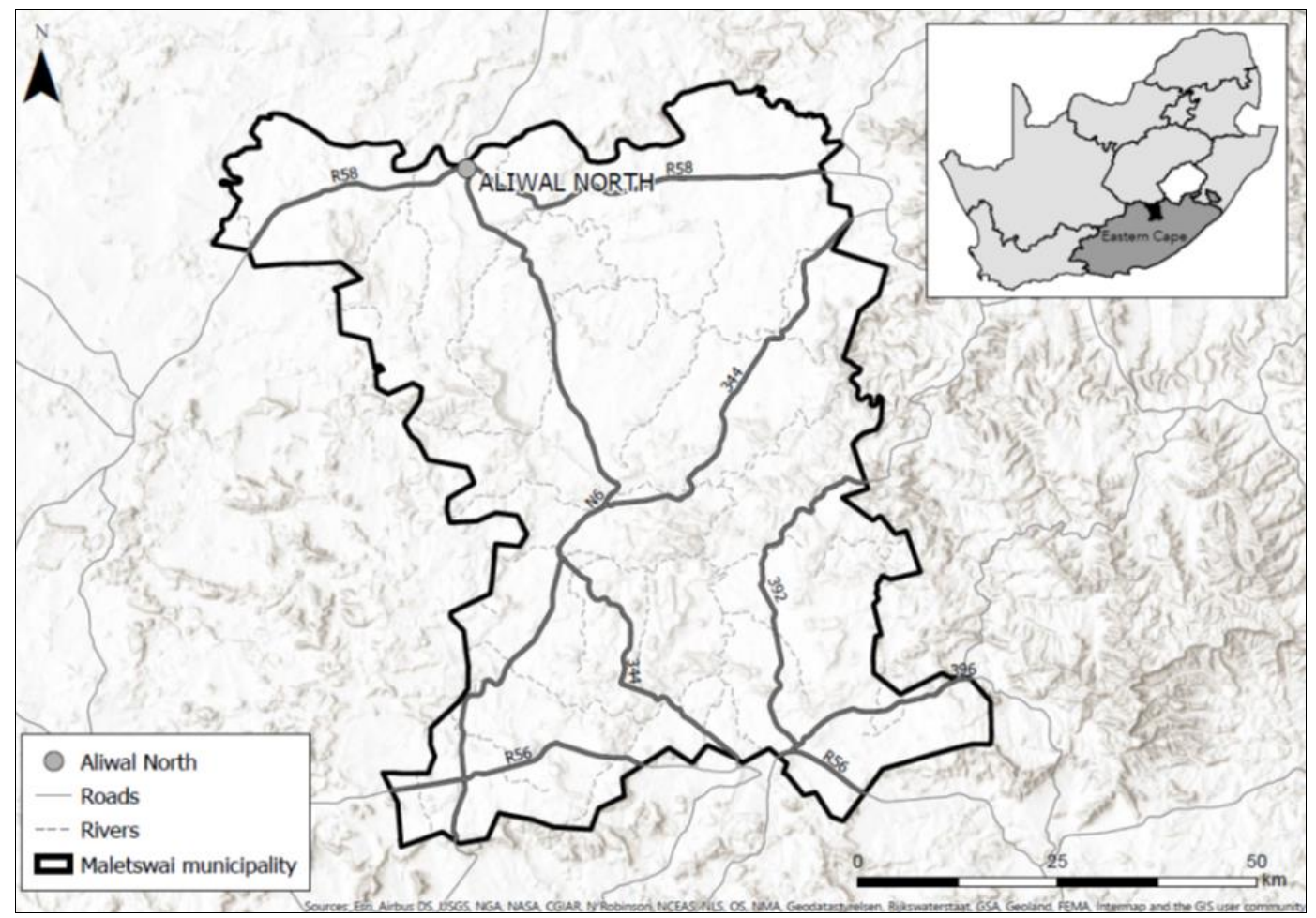

Figure 1. The location of Aliwal North, Eastern Cape Province, South Africa 
From a methodological point of view, the investigation is informed by both primary and secondary data. The primary data was collected from a number of information rich role-players. The interviewees included personnel from the LED units within the local (Walter Sisulu) and district (Joe Gqabi) municipalities of Aliwal North.Other interview participants included representatives from the following organisations: the Joe Gqabi Economic Development Agency (JOGEDA), the Eastern Cape Parks and Tourism Agency (ECPTA), former chairman of the Community Tourism Organisation and members of the Maletswai Business Forum. Secondary data was collected from the following data sources: the Integrated Development Plans of both Walter Sisulu Local and Joe Gqabi District Municipalities; other documents relating to development in Aliwal North; and, planning documents of the Eastern Cape and Parks Agency, Eastern Cape Provincial Department of Economic Development, Environmental Affairs and Tourism and the Joe Gqabi Economic Development Agency. The local tourism marketing brochures were analysed for the purpose of investigating the media representation of Aliwal North as a tourism destination. The key research question was whether or not tourism has become a key economic driver for this town and its hinterland.

\section{NOTES ON THE RELATIONSHIP BETWEEN LED AND TOURISM}

There is no universal definition of LED (Wilson, 1995; Nel, 1999; Rogerson, 2011, 2014; Hristova \& Tast, 2015; Rogerson \& Nel, 2016) - it is described in different ways, but common characteristics do exist. Zaaijer \& Sara (1993:129) define LED as a way in which local stakeholders and government come together to plan, combine resources and include other suitable partners (such as the private sector) with an aim to increase economic activity, which would in turn result in the creation of employment in a locality. Similarly, Hristova \& Tast (2015:385) argued that "Local Economic Development [is] a process in which the local authorities cooperate with the public sector, business community, and NGO's, in order to create a more appropriate environment for economic development and for reducing unemployment. Its objectives are to stimulate investments that will promote sustained high growth in local communities". Rogerson (2014:204) presents LED as economic planning specific to a locality with the purpose of protecting itself from the global and national environments while at the same time maximising opportunities provided by these environments.

There is a seemingly worldwide consensus on the uniqueness of Africa's policy interventions relating to development and LED (Reddy \& Wallis, 2012). Policies developed for other parts of the world are believed to yield different results in Africa, and even policies developed for the continent fail to take into consideration the diversity within the continent and end up failing (Reddy \& Wallis, 2012). RodriguezPose \& Tijmstra (2007) concur with these findings and suggest that LED success in Africa is elusive, with South Africa hailed as an anomaly because of some degree of success being achieved in LED (Nel, 1999; Rogerson \& Nel, 2016; Rogerson, 2019b).

The fall of apartheid brought a turn of events regarding LED planning in South Africa (Rogerson, 2014). LED was made mandatory and spread broadly from big metropolitan areas to include smaller cities and small towns (Rogerson \& Nel, 2016). A plethora of policy legislation pertaining to LED was developed and resources committed for the implementation of LED programmes (Rogerson, 2014). Despite good intentions to implement equal development, however, it further exacerbated unequal development between urban and rural areas. This was largely because it was implemented on an already uneven terrain inherited from apartheid, and resulted in urban areas leading in development, while small towns battled to catch up (Rogerson, 2014; Rogerson \& Nel, 2016). 
The redefinition of the role of local authorities in South Africa is a mandate that has also been considered internationally, as evidenced by Ruhanen (2013). She notes that the role of local authorities has shifted from that of servicing infrastructure, roads and refuse removal to a broader, more developmental focus that involves development planning and implementation (Ruhanen, 2013). In South Africa, the Local Government Municipal Systems Act introduced the Integrated Development Plan (IDP) in 2000.

The IDP is a master plan, unique to each locality, that captures the development objectives of that locality and actions aimed at reaching those goals (The South African LED Network, 2017). Scholars such as Reddy \& Wallis (2012) and Rogerson (2014) deem the release of the 2006 national policy framework document Stimulating and Developing Sustainable Local Economies as crucial in the development of LED policies, and suggest that this document demonstrates maturity in policy legislation. The policy encourages localities to enhance economic inclusivity, ensure the best investment of local resources, maximise the exploitation of local opportunities and increase the locality's competitive advantage to address local challenges such as unemployment (Rogerson, 2014).

The decline in South Africa of economic sectors such as manufacturing, mining and agriculture contributed to the increase of unemployment and the stagnation of many local economies. Government and affected stakeholders needed to find new ways to revitalise local economies and create employment. The New Growth Path (NGP) of 2009 was used as a plan to create a high number of jobs in a limited space of time - the mandate was to be achieved by utilising government policy to untangle structural challenges from the past (Rogerson, 2014). The NGP was criticised for being central planning based and failing to bring local authorities to the planning table (Rogerson, 2014). It therefore failed to take into consideration the uniqueness of localities and the different strategies required for implementation. Reddy \& Wallis (2012) note that in Africa, national government still acts as the main player in the implementation of LED. They claim that national government initiates economic development through targeted policy interventions and infrastructural developments but conclude that in practice it is the private sector that is responsible for delivering economic growth and poverty alleviation in a locality (Reddy \& Wallis, 2012). This practice, noted by Reddy and Wallis, represents a market-led approach to LED and has been the reality of many African countries, including South Africa (Reddy \& Wallis, 2012; Rogerson, 2014, 2019a, 2019b).

The implementation of LED in South Africa is traditionally market led (similar to that of the international approach) but is evolving towards a pro-poor approach (Rogerson, 2011). The preoccupation of the market led approach with economic elements such as employment, income and wealth creation and growth at the opportunistic cost of social and environmental factors is unsustainable. The evolution toward a pro-poor approach in South Africa is evidence that a market led approach has not lived up to expectations (Rogerson, 2019b). Rogerson (2011) is not convinced that the pro-poor approach is the best strategy, claiming that many issues around economic growth are not addressed by it. In South Africa, the application of LED subscribes to a project-based approach which Rogerson (2011) aligns to how the Local Economic Development fund was implemented. The roll-out of the fund was based on municipalities applying for funding to implement projects in sectors such as SMME Development, business incubation and tourism development.

The outcome of the implementation of the fund was small unsustainable projects, with most failing once funding came to an end (Rogerson, 2011). In South Africa's metropolitan areas, the trend now follows that of North America and Western Europe, who prioritise sustainable competitiveness and economic growth (Rogerson, 2011). 
A number of challenges, varying from local to national scales of analysis, face LED practice. Scholars in the field raise a number of concerns regarding the implementation of LED (Ntonzima \& Binza, 2011; Hristova \& Tast, 2015; Rogerson \& Nel, 2016). Ntonzima \& Binza (2011) earmark the lack of integration and cooperation between stakeholders as a huge concern. They say that various government departments, funding institutions and international donors have vested interests in the LED programme, resulting in duplication of efforts and limited impact. They further note that the role of national and provincial government is not absolutely clear and needs to be redefined to ensure efficient and effective implementation of LED. They also raise the issue of scarce accurate data that can be utilised by local authorities to make decisions and develop policy regarding LED. According to Ruhanen (2013) the role of local government in sustainable development should be extended. In trying to achieve their development mandate most local governments in South Africa are faced with challenges such as institutional weakness and limited capacity and skills. Rogerson \& Nel (2016) add the following as challenges faced by the distressed municipalities of South Africa: capacity challenges, insufficient personnel in economic development, a weak institutional capacity and inadequate data for use in planning and decision-making.

\section{AN OVERVIEW OF TOURISM IN THE EASTERN CAPE}

The Eastern Cape Province, in which Aliwal North is located, is endowed with natural beauty, a rugged wild coastline, sandy beaches, a rich culture, heritage, a diversified climate and a stagnant agricultural economy. To complement the natural resources, man-made attractions and infrastructural developments such as accommodation, conference facilities and places of entertainment also render the province an attractive tourism destination. The province links the tourism renowned destinations of KwaZulu-Natal and the Western Cape (Department of Economic Development and Environmental Affairs, 2009). The case study town lies on the banks of the Orange River and was placed on the tourism map by the thermal spring, Aliwal Spa that produces salty water rich in minerals at a temperature of around 34 degrees (Aliwal North, 2016). The population of Aliwal North is estimated in total at 17 ooo, with approximately 5 ooo households. Unemployment in this small community is very high (22\%) (Maletswai Local Municipality, 2013). Agriculture, retail and service industries are the main economic sectors and employers in the town. The town is harshly affected by the El Nino induced droughts experienced across South Africa and therefore the local agricultural industry is not performing well with jobs lost, leaving the community in dire conditions (Maletswai Local Municipality, 2013). Aliwal North has good potential for tourism. It is accessible by road and lies in-between two cities that are accessible by air: East London and Bloemfontein. Aliwal North also acts as a gateway to the province of the Eastern Cape from the northern provinces of South Africa. Situated almost in the middle of the Friendly N6 Route, it serves as a convenient transit stop and overnight destination for travellers to and from the Eastern Cape Coast. It furthermore serves as a major economic hub and meeting and conference destination, especially for the public sector (Maletswai Local Municipality, 2013), and boasts a portfolio of tourism products such accommodation, culture and heritage sites, and eco-tourism and entertainment facilities. These tourism products are supported by an infrastructure of services such as retail stores and banking and transport services (Maletswai Local Municipality, 2013).

\section{Tourism product portfolio of Aliwal North and its hinterland}

Rogerson (2002) asserted that tourism in South Africa is led by private sector developers who evolve small town/rural tourism products as a result of a quest for new 
leisure destinations and targeted tourism-led LED initiatives (Rogerson, 2002). Aliwal North has grown based on both these initiatives. When the hot springs with "healing potential" were discovered, a resort was developed (Aliwal North, 2016). With growth in the popularity of the resort, other services were developed to support the demand from tourists. When in 1994 the new democratic government came to power, it tasked local government with economic development within their localities. Tourism in Aliwal North was purposefully targeted in policy documents by local and district authorities as one of the means to drive local economic development (Maletswai Local Municipality, 2013; Joe Gqabi District Municipality, 2014). Interviewees pointed out that the decision to utilise tourism as a tool for LED in Aliwal North came as a result of the success of tourism in the town in the past. A participant from the Eastern Cape Parks and Tourism Agency estimated that the number of tourists that previously visited Aliwal North during its peak period as a tourism destination was up to 60 ooo people per annum.

This number should be considered within the context of the apartheid government where only white citizens were allowed to travel and enjoy tourism product associated with mainstream tourism (Rogerson, 2015). Other reasons stated for the consideration of tourism-led LED strategies in Aliwal North were the existence of a variety of attractive tourism products and services that enhance the tourism product portfolio and the town's position as the gateway to the Eastern Cape Province from the Northern provinces.

Table 1. Tourism Product of Aliwal North

\begin{tabular}{|c|c|}
\hline Type of tourism product & Categories \\
\hline Accommodation facilities & $\begin{array}{l}\text { Hotels } \\
\text { Guest houses and lodges } \\
\text { Bed and Breakfasts } \\
\text { Camping facilities } \\
\text { Caravan facilities } \\
\text { Farm stays }\end{array}$ \\
\hline Meeting venues & Conference centres \\
\hline Leisure facilities & $\begin{array}{l}\text { Aliwal Spa Resort } \\
\text { Thaba Nkulu Resort }\end{array}$ \\
\hline Culture and heritage & $\begin{array}{l}\text { Museums } \\
\text { Garden of remembrance } \\
\text { Arts and crafts } \\
\text { Rock paintings } \\
\text { Anglo Boer War Memorial }\end{array}$ \\
\hline Nature reserves & $\begin{array}{l}\text { Buffelspruit Nature Reserve } \\
\text { Privately owned game farms }\end{array}$ \\
\hline Activities & $\begin{array}{l}\text { Fishing } \\
\text { Hiking } \\
\text { Hunting } \\
\text { Game drives }\end{array}$ \\
\hline Festivals & Sondela Festival \\
\hline Restaurants & $\begin{array}{l}\text { Catering service } \\
\text { Fast food outlets } \\
\text { Pubs and grills }\end{array}$ \\
\hline Nightlife & $\begin{array}{l}\text { Bars } \\
\text { Night clubs } \\
\text { Taverns }\end{array}$ \\
\hline
\end{tabular}

A further motivation mentioned was that tourism as a strategy for LED had worked in other regions and therefore Aliwal North wanted to replicate that success. 
The significance of a portfolio of tourism products and services that further complement these products was also noted by Binns \& Nel (2002) and Rogerson (2002), as well as Brida \& Pulina (2010). These investigations recommend that destinations should consider a number of conditions when deciding to utilise tourism as vehicle for LED. Diversity of the products on offer is key as it keeps visitors entertained for longer, leading to longer stays and higher spending (Rogerson, 2002).

The first theme that emerged from this investigation was that there is a varied portfolio of tourism products available in Aliwal North (Table 1). A precondition for tourism development is that a destination should have a variety of tourism products available to attract visitors, and as evident from this table, Aliwal North fulfils this requirement. Study participants asserted that the Aliwal Spa Resort was considered the backbone of the tourism offerings of Aliwal North. It was stated that this resort started to deteriorate about 15 years ago and has never been fully restored even after millions of rands have been invested by donors such as the Department of Tourism. The resort is closed for most of the year, with limited operations resuming during December holidays because of demand from the local community. Activities such as the health spa and training facility that are situated within the Aliwal Spa complex were listed as those that suffer owing to the limited operation of the Aliwal Spa Resort.

Interviewees pointed to a seeming mismanagement of the strategic tourism product of Aliwal North. Binns \& Nel (2002) found that proper management of tourism services in Still Bay, for example, was one of the preconditions for the success of tourism as a LED strategy. Binns \& Nel (2002) found that a leader or a champion for tourism (Binns \& Nel, 2002) had a key role to play in the management of tourism as a whole in a destination. It became evident from the interviews that there is no leader or champion for tourism in Aliwal North. Instead, the trend is that the private sector focuses on the management of their own businesses, while the community is powerless and does not know what to do.

Furthermore, various government spheres do what they can in implementing policies amid limited financial and management resources. This means that there is no coordination of efforts between stakeholders. A portfolio of different tourism products is not enough on its own. The availability of services to complement the tourism products, the proper management of tourism within a destination and the availability of a tourism leader should also be accompanied by strong, effective and focused marketing strategies to attract tourists to the destination. The next section will discuss the importance of targeted and coordinated marketing activities and its absence in Aliwal North.

\section{POOR MARKETING OF ALIWAL NORTH AS DESTINATION}

It emerged strongly from the investigation that attempts to market Aliwal North as a tourism destination are limited and inconsistent. The popular option for tourism promotion by the local municipality, the district municipality and the Eastern Cape Parks and Tourism Agency is the attendance of trade shows such as the Tourism Indaba, Johannesburg Expo and the Cherry Festival in Ficksburg. Representatives from these organisations attend the shows and take along brochures, presentations and other marketing material from various local tourism businesses. When attending some trade shows and when the budgets permit, they invite and pay for small businesses to also attend these shows. Nevertheless, it emerged that there are few tangible benefits of the marketing attempts. As one interviewee remarked: "All they come back with are bags full of freebies and brochures from other destinations". Further evidence came from the marketing materials that were analysed as part of secondary data collection. The regional brochure of the Eastern Cape Highlands (Fig 2) was funded by the Joe Gqabi District 
Municipality. It is a generic brochure that focuses on the whole Joe Gqabi region. Furthermore, the brochure vaguely and briefly presents Aliwal North as a historical town that is home to the Aliwal Spa Resort. The only picture of the Maletswai locality shown by the brochure is that of the Aliwal Spa Resort. The brochure utilised a picture of a resort that is now non-operational during most parts of the year as a means of attracting tourists. This shows how unfocused the attempt is at place marketing.

Figure 2 showcases the "Friendly N6 Route" brochure. The brochure features the town of Aliwal North as a tourism attraction; in particular, it is described as a caravan heaven and historical town. The interesting thing about the Friendly N6 Route brochure is that it does not even mention the existence of the Aliwal Spa Resort.

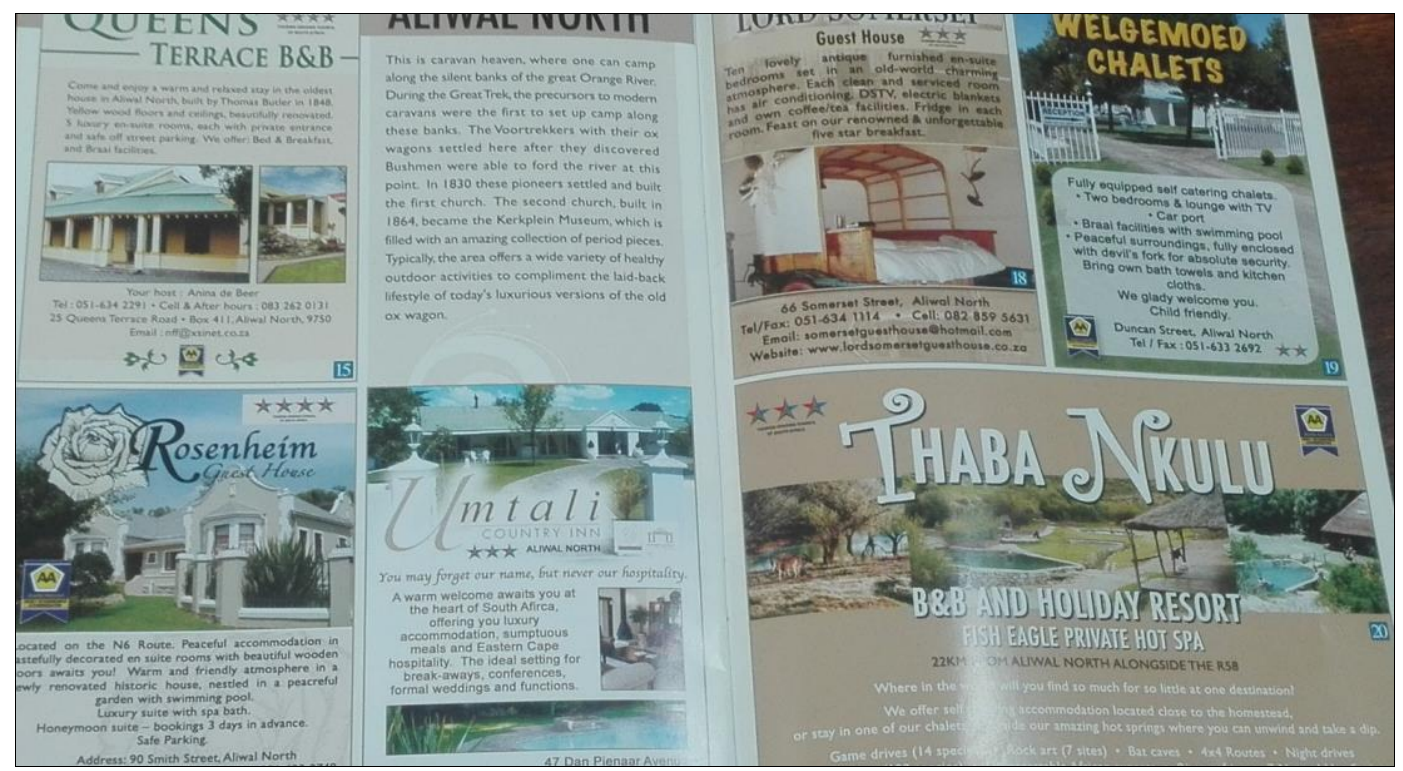

Figure 2. Aliwal North featured in the Friendly N6 brochure

A contradiction is noted regarding the two brochures that were analysed. The Eastern Cape Highlands brochure, funded by government, features and presents the Aliwal Spa Resort as a tourist attraction. On the other hand, the Friendly N6 Route brochure, which is the marketing effort by the private sector, does not mention the Aliwal Spa Resort. This contradiction underlines the uncoordinated efforts of the stakeholders within the tourism space of Aliwal North. "Tourism is not our competency" noted the local municipality concerning the marketing initiatives and the limited budget allocated for marketing tourism within the municipality. This response is in contrast with an earlier claim by the same participant that suggested that "[the municipality] will always find a way to harness tourism as it is our cash cow". There is a contradiction present in the negation of the responsibility for tourism on the one hand and the willingness to benefit from tourism on the other. The lack of marketing initiatives was confirmed by other survey participants from the Joe Gqabi Development Agency.

There are currently no efforts made by the agency to market Aliwal North as a tourism destination. The respondents claimed that the agency will initiate a marketing programme from its side once the Aliwal Spa Resort is fully developed and operational. A study participant from the Eastern Cape Parks and Tourism Agency (ECPCA) was not 
aware of the existing marketing campaigns in the region and in Aliwal North, despite being mandated with the development and marketing of tourism within the Eastern Cape Province. The fragmented nature of the marketing activities can be seen as separate and uncoordinated marketing activities by the private sector businesses on the one hand and the public sector on the other, each pursuing marketing activities geared towards their perceived target markets. The question of the effectiveness of the chosen marketing initiatives needs to be considered further. Insight into who the target market is, the distribution channel for the marketing material and what can be done to enhance these attempts needs to be improved. The Trade Led Tourism Growth Strategy for the Eastern Cape (Eastern Cape Tourism Board, 2010) made a recommendation for the formation of joint marketing partnerships by public and private sector companies who have expertise and knowledge about who the client is and what they are looking for.

In order to implement this recommendation, relationships with key stakeholders would have to be initiated, nurtured and maintained. This leads us to the following issue: the lack of coordinated stakeholder relationships in Aliwal North.

\section{STRAINED STAKEHOLDER RELATIONSHIPS}

The mismanagement of tourism in Aliwal North, as well as the uncoordinated marketing efforts discussed, are just some of the issues that point to a lack of sound stakeholder relationships in Aliwal North. This is of concern as various scholars (Zaaier \& Sara 1993; Rogerson, 2002) and development organisations (United Nations, ILO, South African LED Networks), in their definition and discussions of local economic development, emphasise the importance of sound stakeholder relationships.

Local municipality functionaries identified the private sector, community tourism organisations and other government departments and entities as their main stakeholders in both tourism development and the implementation of LED. The South African LED Network (2017) advises that specific responsibilities should be given to the various stakeholders identified so that there is a clear path of who needs to do what and what is expected from whom. The roles were allocated as follows: the private sector drives LED, governments create a conducive environment for the implementation of LED through policies, infrastructure provision and by-laws and the communities should identify and exploit local resources for their own benefit. This same role clarification was featured on the 1996 White Paper on the Development and Promotion of Tourism Development in South Africa. The dilemma is whether the clarification of roles is reflected in practice and whether it is in fact influenced by the way they are presented within the White Paper.

Strained stakeholder relations emerged as a challenge to tourism development and the implementation of LED. The private sector business owners as members of the local business forum voiced their distrust in government, specifically the local municipality. The claim was that the local municipality does not know what they are doing and therefore they were putting private businesses at risk through their failure to provide much needed basic resources such as water and electricity, both vital enablers of tourism.

The politicisation of labour also emerged as a critical issue that has led to both job losses and closure of small businesses. Members of the local business forum expressed frustration because of unsuccessful attempts at getting the local municipality to attend discussion forums. The local municipality is perceived as seeing the value of private business only when it wants to 'tick the box' of public participation in its policy development process. The study participants from the local business forum were positive about the mandate of tourism as a driver of LED. They shared that they had previously formed a steering committee with the municipality with the aim of fast-tracking the 
completion of the Aliwal Spa Resort refurbishments and getting it ready to be opened for business. They spoke of deals that were discussed and planned with companies that provide tourism management services to oversee the operations at Aliwal Spa. It was noted that site visits were conducted at similar resorts that were managed by the destination management company and a contract was ready to be signed when the local municipality, as the owner of the Aliwal Spa Resort, reneged on the deal made. The participants explained that the identified destination management company mentioned had placed a condition on the proposed deal. The condition was that the destination management company did not want to sign a contract with the local municipality because the fluid nature of municipalities results in little guarantee that the same political party would be in power for the duration of the contract. The destination management company did not want to forge new deals and sign new contracts each time there was a change of power at the municipality. A proposal was made that Joe Gqabi Economic Development Agency (JOGEDA) should co-sign the contract and act in lieu of the municipality. The municipality did not agree and reneged on the deal. According to the study participants, the result of these actions by the municipality led to mistrust and frustration.

The collapse of the local tourism association together with small businesses' exit from tourism also emerged as issues in local stakeholder relations. The view is that these stakeholders realised that there is no direct benefit from tourism and did not want to invest their resources haphazardly. A contradictory view was expressed by other study participants from government and the private sector which asserted that the local community was passive and waited for action and orders from government.

Overall, there is therefore a lot of finger pointing among the stakeholders. Trust was broken between stakeholders, resulting in each working on their own, in isolation. The challenges to tourism implementation as a tool for LED are not limited to those discussed above. Capacity and funding for tourism were also identified as major issues.

\section{LIMITED CAPACITY AND FUNDING FOR TOURISM}

One of the themes that emerged from this investigation is the limited capacity and funding for tourism development and LED implementation. This comes despite the fact that the tourism sector has been highlighted as a key driver of LED. The National Tourism Sector Strategy of 2011 already identified capacity and funding as constraints for tourism (National Department of Tourism, 2011). During fieldwork conducted in 2017, these concepts were still raised as obstacles for tourism by some. Participants from the local and district municipalities maintained that there was enough human resource capacity to perform LED activities. They raised the issue of limited budgets for travel and implementation as the constraint that made their organisations seem incapacitated.

According to them, this challenge limited the impact derived from the implemented projects. "Often things are done just for compliance (top management), not taking into consideration how effective or efficient they might be. Local government departments are fragmented in their approach and work in silos", was the conclusion. On the other hand, governments' inability to plan for and implement LED emerged as a concern from the interviews conducted with the private sector. Another observation was that the local municipality has no budget set aside for tourism development. The norm was reliance on the district municipality that has a budget of R250 ooo for LED implementation for the whole region. The budget includes the implementation of LED activities within other sectors as there is no separate budget for the implementation of tourism development projects. The Joe Gqabi Economic Development Agency, an agency developed and mandated to drive economic development within the district, also does not have 
dedicated funds for tourism development and LED implementation and relies on external donors such as the Eastern Cape Development Corporation, the Industrial Development Corporation and the Department of Tourism for funding of specific projects.

These emerging challenges are not unique to this locality as similar results were found by Rogerson \& Nel (2016) as well as Lawrence \& Rogerson (2019) in their research on planning for local economic development in distressed areas. They found that municipalities face the following challenges in their pursuit of successful LED strategies, capacity constraints for LED planning and implementation, limited human resource capacity within the municipalities, funding shortages, and inadequate data or research to inform targeted LED planning and implementation. Attempts to address these challenges should begin at national policy level. Drawing from national policy, the local authorities can tailor-make their own solutions based on locality strengths and weaknesses. The town of Aliwal North satisfies the precondition of owning a varied number of tourism products together with services that enhance the tourism products, required for a successful tourism destination. Findings from the data collected show that there is a willingness to utilise tourism to drive LED in Aliwal North. It is also evident that a number of constraints negatively impact tourism development and LED implementation.

\section{CONCLUSION}

For a destination to be able to attract tourists, a portfolio of tourism products and supporting services needs to be accompanied by appropriate tourism management, aggressive marketing activities, funding for tourism and good stakeholder relationships. The findings of this study positively point to availability of a mix of tourism products to attract visitors to Aliwal North, a host of support services and the advantages of being both the gateway to the Eastern Cape Province from the Northern provinces and the main economic centre of the Joe Gqabi District Municipality. Challenges indicated by the findings of this study include the mismanagement of tourism, limited capacity and funding for tourism, as well as broken stakeholder relationships in Aliwal North.

An investigation of documents such as the Joe Gqabi District Local Economic Development Strategy and the Integrated Development Plans of the Maletswai Local and Joe Gqabi District Municipalities revealed that tourism is featured as a possible LED strategy for Aliwal North. In practice, however, tourism is not a priority and is haphazardly planned. At the local municipality, district municipality and at the Joe Gqabi Economic Development Agency there are no personnel employed solely for promoting and managing tourism. Rather, tourism is managed by the local economic development personnel. Some of these personnel do not have specific qualifications in tourism and/or experience working within the tourism sector. There was scant evidence of specific plans for further tourism development in the reviewed documents from the local municipality, such as plans to develop the local nature reserve through funding from the Department of Environmental Affairs. The claim made by Visser \& Hoogendoorn (2012) that the benefits of tourism in South Africa can be traced back to the marketing campaigns of South African Tourism is a clear indication of the significance of marketing within tourism destinations. Hytia \& Kola's (2013) research in Eastern Europe also showed how poorly tourism performs in destinations where reliance is placed on tourism products with marketing initiatives ignored.

Findings from the study indicate that Aliwal North as a destination is not receiving optimal marketing. The current marketing initiatives are generic, lack focus and prove that implementation is only done for the sake of implementation. No evidence exists of awareness about the target market or the appropriateness of platforms and tools to reach that target market. Stakeholder relationships are 
highlighted in the literature as key elements in the implementation of local economic development. Agreement exists on the coming together of the different role players in society who have varied expertise and can create a suitable environment for LED implementation. Evidence from the study showcased broken relationships between local authorities and private business as well as between the community and the local authorities, and a non-existent relationship between the community and private business. The study participants also spoke of a mistrust of the local authorities. Therefore, the situation presented here dictates fragmentation which can be viewed as a constraint to successful tourism development and LED implementation.

Limited capacity for tourism emerged in contrasting views. The study participants from the local and district municipalities claimed capacity for tourism development and LED implementation is adequate. They placed blame on limited budgets for travel and operations. The private sector on the other hand pointed at government as incapable of tourism development and LED implementation. The research conducted by Rogerson and Nel (2016) in distressed municipalities, which include the municipality within which the town of Aliwal North falls, pointed to institutional as well as human resource capacity challenges as great obstacles in these areas. Limited funding for tourism development and LED implementation are also causes for concern. As noted by Rogerson \& Nel (2016), most South African localities do not set aside funds for tourism. With such limited dedicated funding, the implementation of LED initiatives will remain a challenge. This was supported by a respondent from the district municipality who argued that the impact of implemented initiatives was sporadic and insignificant due to limited funding. It can be concluded that tourism, as it is currently implemented in the town of Aliwal North, is probably not the best strategy to drive LED within the town. A key tourist attraction is not operational, a budget is not set for further development of tourism, there is no research being conducted to analyse markets and trends for the town, and marketing activities are few and not suitably focused. There is also an implication of a lack of capacity to implement tourism-based LED and limited evidence of successful implementation. In the end this investigation re-affirms Lawrence \& Rogerson's (2019:155) observation that any [tourism] development agency[ies] is contingent upon the establishment of partnerships amongst stakeholders, a committed and visionary leadership, an entrepreneurial approach undertaken within the maintenance of the public interest, a clear strategic vision for local development and the appropriate mobilisation and valorisation of local development assets.

\section{Acknowledgements}

Thanks to Teddy, Dawn and Skye Norfolk for editorial assistance on this paper.

\section{REFERENCES}

Binns, T. \& Nel, E. (2002). Tourism as a Local Development Strategy in South Africa. The Geographical Journal, 168(3), 235-247.

Brida, J. G. \& Pulina, M. (2010). A Literature Review on the Tourism-led Growth Hypothesis. Cagliari: CUEC. Donaldson, R. (2018). Small Town Tourism in South Africa. Dordrecht: Springer.

Hristova, S. \& Tast, J. (2015). The Emergence and Significance of Local Economic Development. Economic Development, 3, 379-398.

Hyytia, N. \& Kola, J. (2013). Tourism Policy as a Tool for Rural Development. Applied Economics Perspectives and Policy, 35(4), 708-730.

Lawrence, F. \& Rogerson, C. M. (2019). Local Economic Development Agencies and Peripheral Small Town Development: Evidence from Somerset East, South Africa. Urbani izziv 30 (supplement), 144-157.

Meyer, D. F. \& Meyer, N. (2015). The Role and Impact of Tourism on Local Economic Development: A Comparative Study. African Journal for Physical, Health Education, Recreation and Dance, 21(1:1), 197-214. 
Milne, S. \& Ateljevic, I. (2001). Tourism, Economic Development and the Global-Local Nexus: Theory Embracing Complexity. Tourism Geographies, 3(4), 369-393.

Nel, E. (1999). Regional and Local Economic Development in South Africa: The Experience of the Eastern Cape. Aldershot: Ashgate.

Ntonzima, L. \& Binza, M. S. (2011). Prioritisation of the Tourism Industry as a Local Economic Development Sector Approach for Rural Coastal Areas in South Africa: The Case of the Transkeian Wild Coast Community. Journal of Public Administration, 46(1), 654-667.

Reddy, P. \& Wallis, M. (2012). Local Economic Development: A Critique of the African Experience. Politeia, 31(2), 70-88.

Rodriguez-Pose, A. \& Tijmstra, S. (2007). Local Economic Development in Sub-Saharan Africa. Environment and Planning C: Government and Policy, 25, 516-536.

Rogerson, C. M. (2002). Tourism-led Local Economic Development: The South African Experience. Urban Forum, 18(2), 49-68.

Rogerson, C. M. (2011). Tracking Local Economic Development Policy and Practice in South Africa, 1999-2009. Urban Forum, 22, 149-168.

Rogerson, C. M. (2014). Reframing Place-based Economic Development in South Africa: The Example of Local Economic Development. Bulletin of Geography: Socio-Economic Series, 24, 203-218.

Rogerson, C.M. (2015). Tourism and Regional Development: The Case of South Africa's Distressed Areas. Development Southern Africa, 32, 277-291.

Rogerson, C.M. (2019a). Peripheral Tourism Trajectories: Evidence from King Sabata Dalindyebo Municipality, South Africa. GeoJournal of Tourism and Geosites, 26 (3), 974-992.

Rogerson, C. M. (2019b). Revamping Local Economic Development Policy in South Africa. In J. Knight \& C.M. Rogerson (Eds.), The Geography of South Africa: Contemporary Changes and New Directions. Cham: Springer, 253-260.

Rogerson, C.M. \& Nel, E. (2016). Planning for Local Economic Development in Spaces of Despair: Key Trends in South Africa's 'Distressed Areas'. Local Economy, 31(1-2), 124-141.

Rogerson, C.M. \& Rogerson, J.M. (2019). Tourism, Local Economic Development and Inclusion: Evidence from the Overstrand Local Municiality, South Africa. GeoJournal of Tourism and Geosites, 25 (2), 293-308.

Ruhanen, L. (2013). Local Government: Facilitator or Inhibitor of Sustainable Tourism Development? Journal of Sustainable Tourism, 21(1), 80-98.

Sharpley, R. \& Harrison, D. (Eds.) (2019). A Research Agenda for Tourism and Development. Cheltenham: Edward Elgar.

Visser, G. \& Hoogendoorn, G. (2012). Uneven Tourism Development in South Africa: Another Ongoing Struggle. Africa Insight, 42(2), 66-75.

Wilson, P. (1995). Community Based Economic Development in the USA and Latin America. In: C. Demaziere (Ed). Local Economic Development in Europe and the Americas. New York: Mansell, 203-212.

Zaaijer, M. \& Sara, L. M. (1993). Local Economic Development as an Instrument for Urban Poverty Alleviation: A Case from Lima, Peru. Third World Planning Review, 15(2), 128-142.

*** Aliwal North (2016). Aliwal North.net. http://www.aliwalnorth.net, Accessed 10 July 2016.

*** Department of Economic Development and Environmental Affairs (2009). Eastern Cape Tourism Master Plan 2009-2014. Bisho: Department of Economic Development and Environmental Affairs.

*** Eastern Cape Tourism Board (2010). Trade-led Tourism Growth Strategy for the Eastern Cape. East London: Eastern Cape Tourism Board.

*** Joe Gqabi District Municipality (2014). Local Economic Development Strategy Review. Barkly East: Joe Ggqabi District Municipality.

*** Maletswai Local Municipality (2013). Integrated Development Plan 2013. Aliwal North: Maletswai Local Municipality.

*** National Department of Tourism (2011). The National Tourism Sector Strategy. Pretoria: National Department of Tourism.

*** Republic of South Africa (2017). New Growth Path Framework. http://www.economic.gov.za/ communications/publications/new-growth-path-series.

*** The South African LED Network (2017). LED in South Africa. led.co.za/led-in-south-africa, Accessed 15 May 2017.

Submitted:

10.07.2019
Revised:

16.12.2019
Accepted and published online 17.12.2019 